International Journal of Engineering \& Technology, $7(4.34)(2018)$ 167-172
SPC
Website: www.sciencepubco.com/index.php/IJET
Research paper

\title{
Investigation of Road Bank Failures based on Mineralogical Composition Studies in Kano-Abuja Road Northern, Nigeria
}

\author{
Mohd Khairul Amri Kamarudin ${ }^{1,2 *}$, Musa Garba Abdullahi1 ${ }^{2,3}$, Mohd Hariri Arifin ${ }^{4}$, Roslan Umar ${ }^{2}$, Muhammad \\ Hafiz Md Saad ${ }^{2}$, Iya Garba ${ }^{5}$ \\ ${ }^{1}$ Faculty of Applied Social Science (FSSG), Universiti Sultan Zainal Abidin, Gong Badak Campus, 21300 Kuala Nerus, Terengganu, \\ Malaysia \\ ${ }^{2}$ East Coast Environmental Research Institute (ESERI), Universiti Sultan Zainal Abidin, Gong Badak Campus, 21300 Kuala Nerus, Ter- \\ engganu, Malaysia \\ ${ }^{3}$ Department of Physics, Yusuf Maitama Sule University, Kano, P.M.B. 3220, Kofar Nasarawa, Kano- Nigeria \\ ${ }^{4}$ Department of Geology, School of Environmental and Natural Resource Sciences, Faculty of Science and Technology, \\ Universiti Kebangsaan Malaysia, 43600Bangi, Selangor, Malaysia \\ ${ }^{5}$ Department of Geology, Kano University of Science and Technology, Wudil, Kano-Nigeria \\ *Corresponding authorE-mail: mkhairulamrir@unisza.edu.my
}

\begin{abstract}
This article investigated the general compositions of the areas (the road) including the geology, mineralogy, and geochemistry to explore the reason for the road failure. The zone is underlain basement (storm cellar) and sedimentary rocks of different textures, mineralogy, and geochemistry. The results implies that the areas that is most stable along the road portions is underlain by the granite-gneiss, granites, amphibole schist and quartz, schist and small sandstone while portions with the failures are underlain by mica schist, phyllite, and coarse-grained granite. It is apparently sure from this study that poor quality metasedimentary rocks constitute the formation of the failed portions. However, the high numbers of the sediment and sandstone present in the area that can easily be weathered due to the climate variation have increased the failure. In conclusion, the result will help the engineers during reconstruction of these parts need to be excavating deeply and replace with granite-gneiss, granites, amphibole schist and quartz for better result.
\end{abstract}

Keywords: Geochemistry; Geology, Mineralogical composition; Geomorphological; Topography.

\section{Introduction}

Roads in Nigeria are constructed with either lack of management, inferior construction materials, and inadequate engineering study. These attributed to the monotonous consideration of the basement and sedimentary terrains which causes failed portions of the road $[1,2]$. The Shear strength, compaction, and compressibility studies have shown that basement and sedimentary rocks could respond considerably to stress and environmental influence as a result of their variation in mineralogical and chemical composition $[3,4]$. The understanding of the lithology of the underlying parent rocks and soils used in the construction of road play an essential role in the stability and performance of any road. However, the dangerous portion of the streets is as a result of incompetent base materials and basement rocks or poor construction materials and management $[5,6]$. It is responsible for fatal road carnage, wearing down of vehicles and waste of valuable time during transportation of goods and services.

A few literatures where discussed in other parts of the road. For example; [7] distinguished strange low resistivity zone and depicted major and minor straight breaks that guide in the connection of water with basement rocks and incredibly decreased the baseshake and subsoil shear qualities coming about into unremitting road carnage. [8] examined the reason for roads failure along Ilesa - Akura roadway utilizing remote sensed and geotechnical information and inferred that linear geological features are the zone of weakness that enhance the accumulation of water leading to failure of some segments in the study roads. Reconciliation of land, geological, mineralogical and geochemical study of the fundamental parent rocks to compliment geotechnical survey on foundation engineering problems cannot be overemphasized. In [9] credited the road failure of Oyo - Ogbomosho Road to environmental factors. This study consequently integrated geology, mineralogy, and geochemistry to explore the cause of failure of Kano-Abuja federal highway in northern Nigeria.

\section{Materials and method}

\subsection{Geology of the Study Area}

The study area, which is located on Basement Complex, is underlined by gneiss-migmatite complex, metasediments (schists and quartzites of the schist belts) and granitic rocks of the Older Granites series. Minor dikes were found within these major rocks (Gneisses, migmatites, schists, quartzites etc.). The Basement Complex ranges in age from the Liberian (c. 2,800 Ma) to the Upper Proterozoic (c. $600 \mathrm{Ma}$ ). The Older Granites, which intruded the gneiss-migmatite complex and the metasediments (schist belts), consist of porphyritic, medium and fine-grained varieties of granites, granodiorites, syenites, diorites, and gabbros are mostly products of Upper Proterozoic (Pan-African) event (750-450 Ma). There are also the minor dikes such as pegmatites, aplites and 
quartz vein that are either concordant with the general strike or cross cut these rocks and are the youngest rocks in the basement. In [10] identified the thin presence beds of Kaolinitic clay overlain by lateritic soil and sandstone/ferruginous sandstone within the sandstone formation, and suggest basement provenance of the Kaolinitic clay.

\subsection{Method}

The Geological mapping was carried in the study area with more emphasis on projections along the study road network. Many rock types coming across were observed in hand specimen for considering their texture, structure, color and their relationship with each other. Rock samples were obtained at different locations for both the stable portions and the failed portions of the road sections. We used the geological hammer in removing some type of rocks which is hard to remove with hand. The samples were choosing differently from different locations and were labeled according to the name of the locations. All the samples were taken to the laboratory, and performed whole-rock chemical and mineral analyses. Jaw crusher was used against the rock samples and disintegrated it into smaller pieces. The pieces were pulverized using FRITSCH Pulverisette. However, the Pulverized rock samples of smaller grams were sieve by allowed passing through $20 \mathrm{~mm}$ meshes. It was then carried for the mineralogical and geochemical analyses. We use X-ray Diffraction (XRD) and Inductively Coupled Plasma mass spectrometry (ICP-MS) methods at Activation Laboratory. According to [11], rock identification will be a deliberate process, requiring concise, exact portrayals of physical qualities. This transform may be called petrography. Geologists utilize petrographic portrayals to demonstrate the crucial features of rocks in illustrations if appropriate. Petrographic portrayals additionally outline these aspects to future reference. They help with additional data which can easily help in identification of the rock.

This Deliberate petrographic description, as suggests to be called, ought to follow a deliberate process in itemizing those essential data in a set request. Geologists required to have the capacity to determine those physical properties from rocks in view of perceptions what is more basic tests that could carried out in the field [11].

Also, in [12] described that a suitable methodology to geological mapping will be the initial framework to the real lithological part. The effectiveness of the information gathering gives a spatial example in the determination that much surpasses conventional geochemistry in the place for mineral investigation focuses by geochemistry such as the group rocks, mineralization. Alternately this might make used to aide further investigation. Information might likewise give a fantastic aide as of the provenance from apply for surface material.

However, in [13] implies that Ground states including geological, geotechnical, and hydrological conditions, have a significant effect on the planning, design, development and repairind of a road, and frequently figure out its possibility What's more causes of its damages. Fundamentally, subsurface investigation will be the practically paramount types of investigations that will help in acquire the road surface conditions, as it may be helpful to those techniques implies for the construction and repairing of roads.

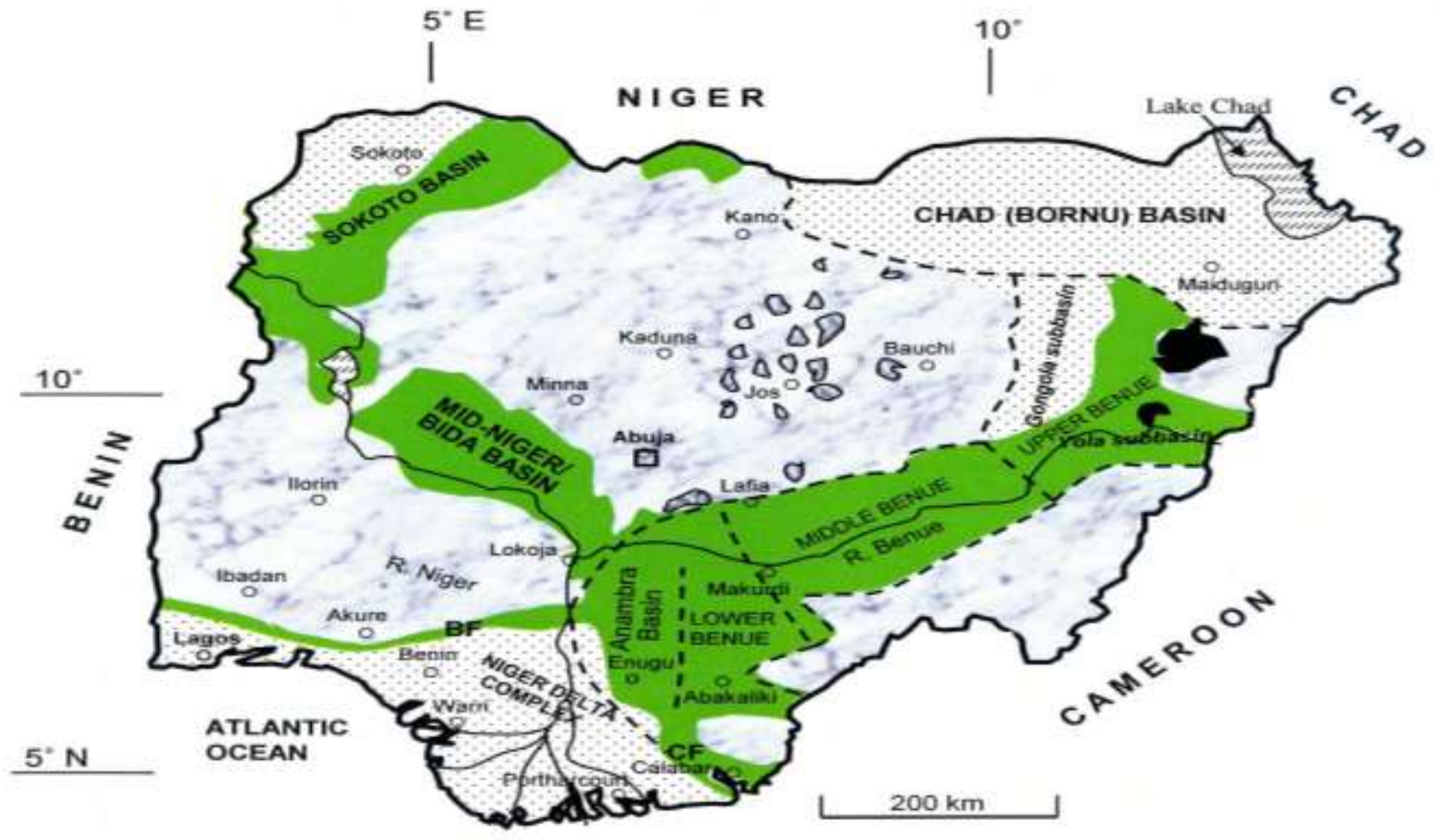

Fig. 1.1. Geological sketch map of Nigeria showing the major geological components: Basement, Younger Granites, and Sedimentary Basins
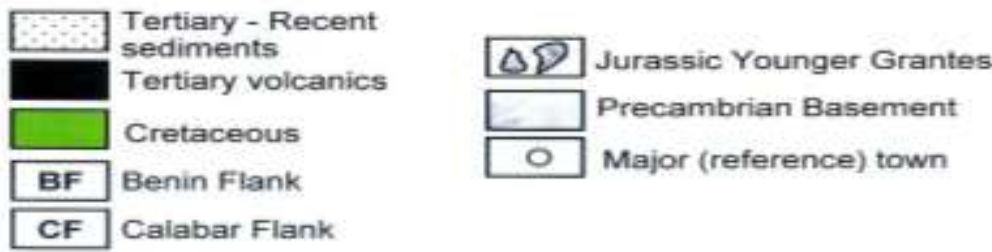

Fig. 1: Geoligical sketch map of Nigeria after [14] showing the major geoligical components: Basement, Younger Granites and Sedimentary Basins 


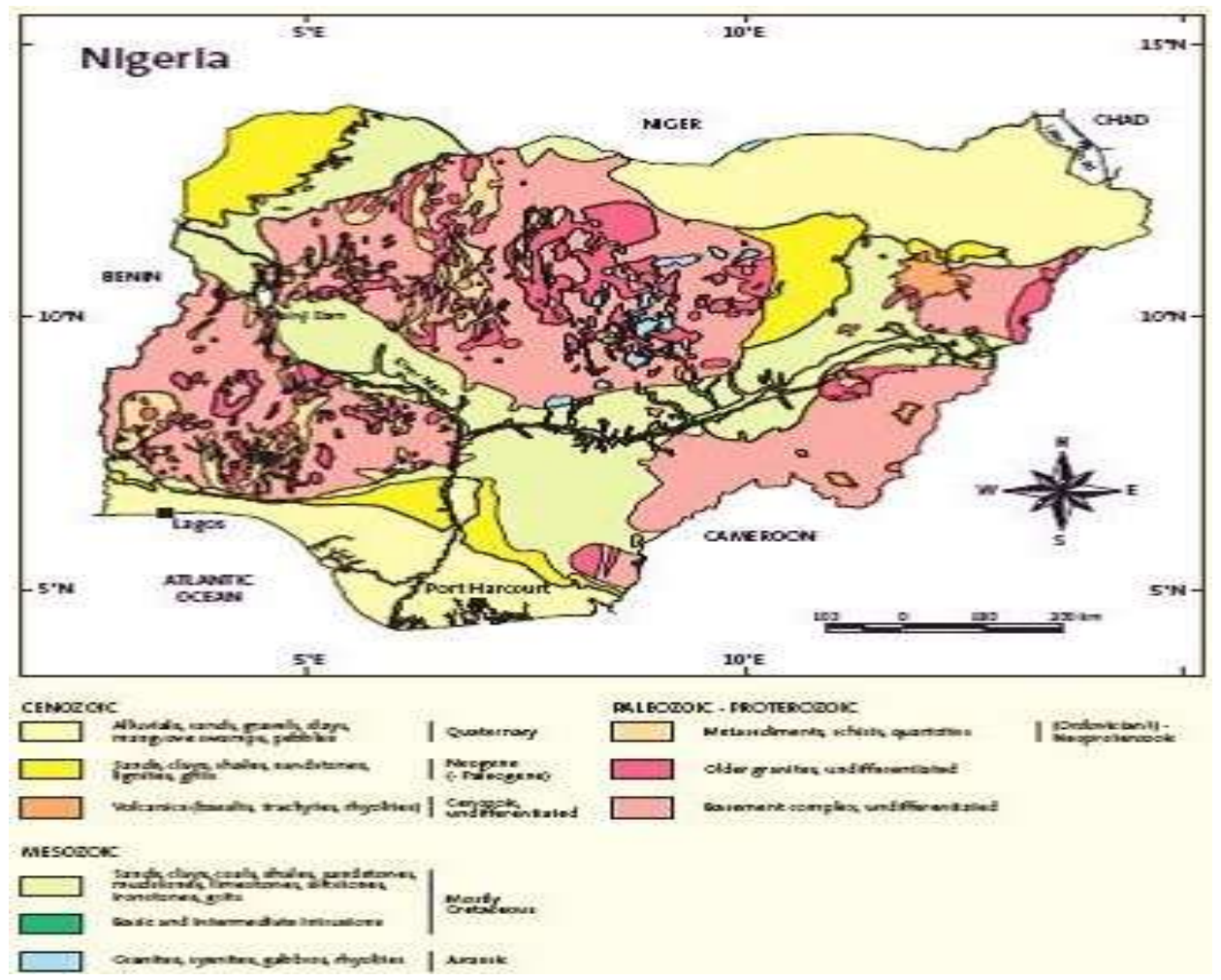

Fig. 2: Distribution of rocks in Nigeria after [14]

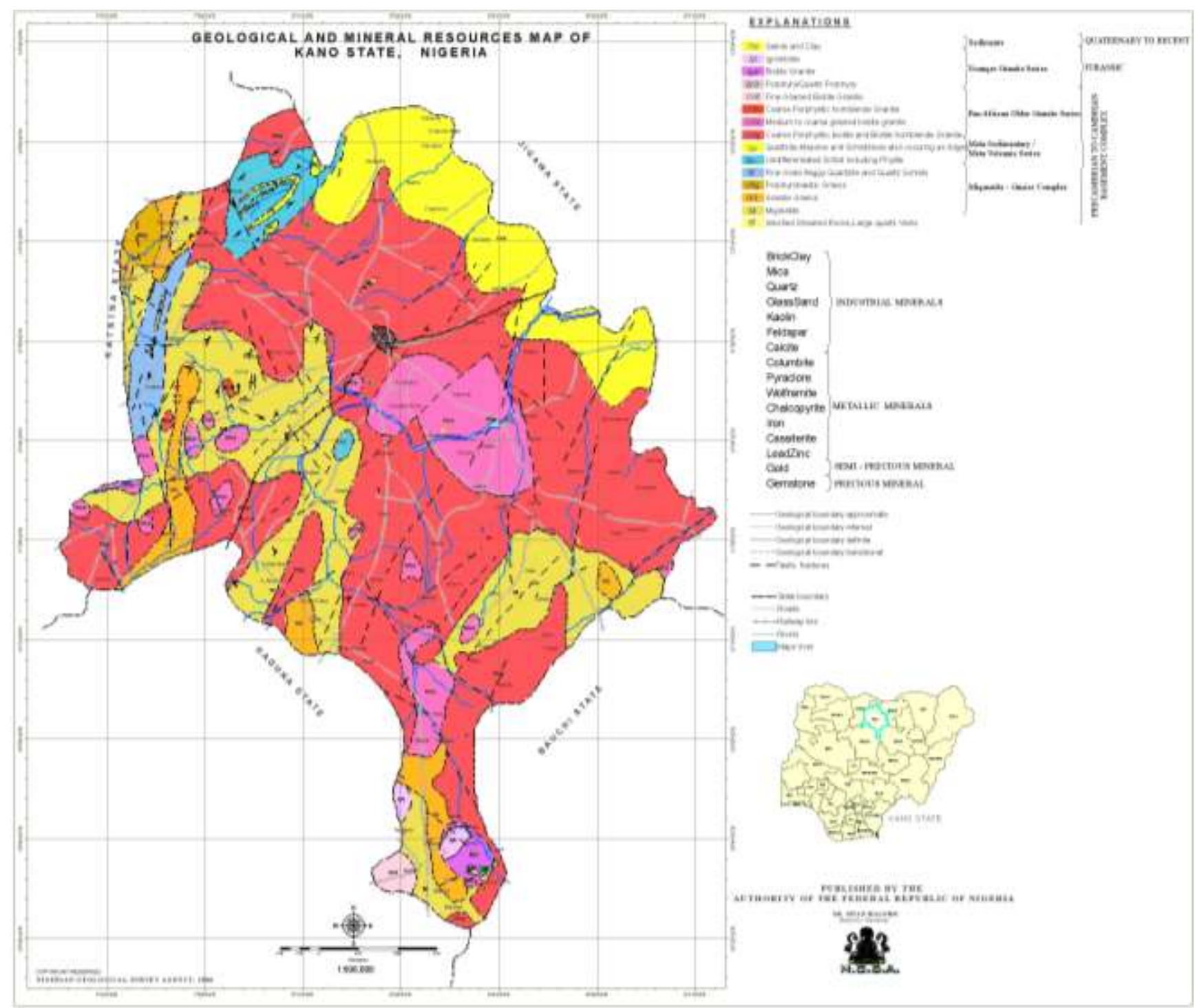

Fig. 3: Distribution of rocks in Kano State after [14] 


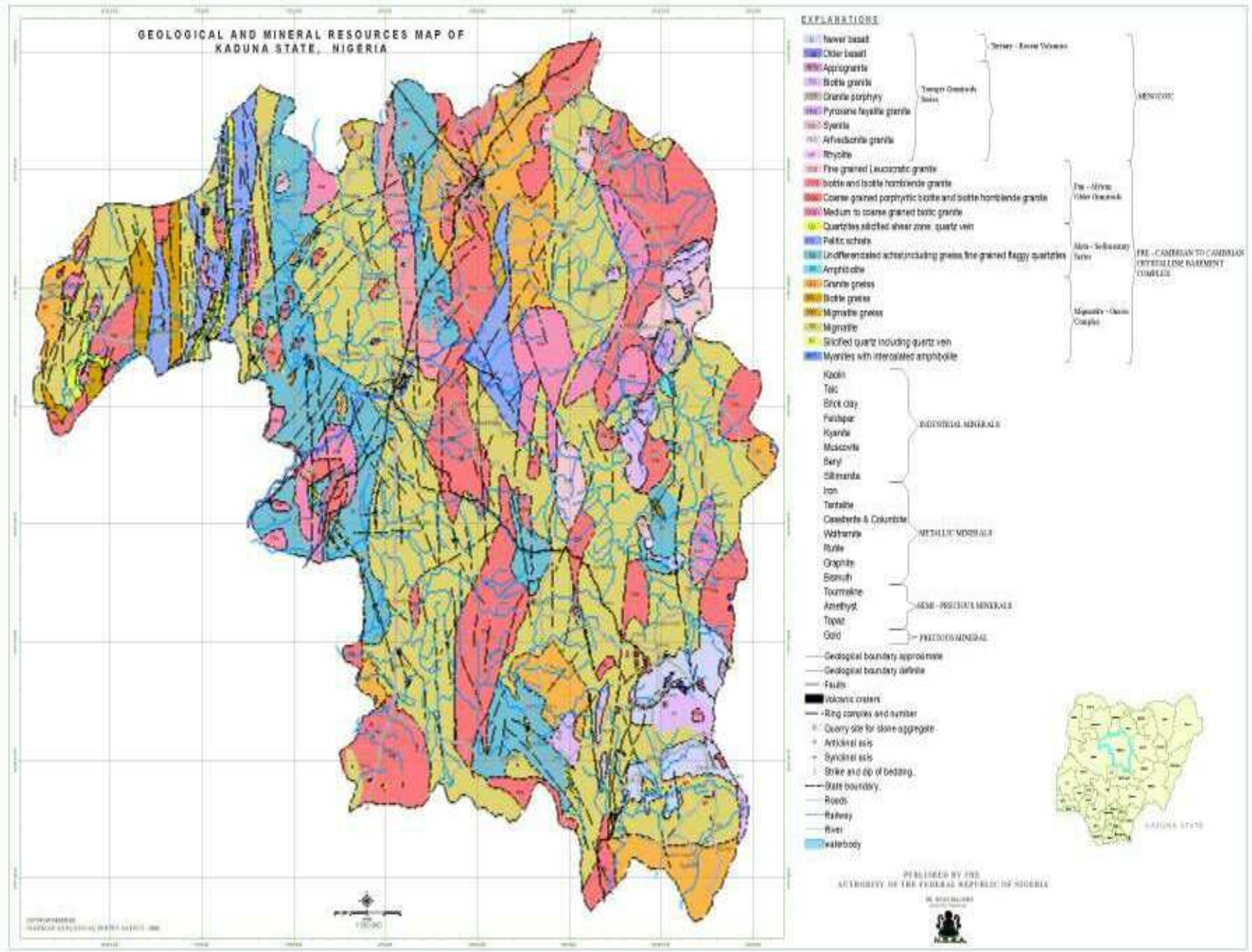

Fig. 4: Distribution of rocks in Kaduna State after [14]

\section{Results and discussion}

The results and discussion of this finding are categorized into subsections. It starts with the geology of the study area, and mineralogy followed by geochemistry.

\subsection{Geology and Mineralogy}

The rock types along the study road network include; granitegneiss, medium grain biotite, and muscovite granite, porphyritic granite, mica schist, amphibolites schist, quartz schist phyllite and sandstone as revealed through geological mapping. The area that is most stable along the road portions is underlain by the granitegneiss, granites, amphibole schist and quartz, schist and sandstone. While portions of the road with patches and roughness is underlain by mica schist, phyllite, and coarse-grained granite Structurally, most of the granites are open jointed, and in some areas dissected by quartzo-feldspathic veins. The granitic rock underlies about $48 \%$ of the study area while phyllite, schist, and amphibolite schists are about $43 \%$ and sandstone $5 \%$. Schist is strongly foliated ranging from muscovite schist to biotite schist trending in the north - Southwest and occurred mostly in the northern section of the study road network. In hand specimen, the schist varies from leucocratic to melanocratic, the leucocratic show effects of chemical weathering. Amphibolite schist occurred along Zaria inter-layered with quartz schist, and mylonite, the rock around Zaria area is constrained and time saw intruding the schist. Phyllite is also common in the northeast and northwest sections of the study road and closely associated with schist, characterized by a silky sheen on the cleavage surface and show evidence of inten- sive weathering at the surface where they outcrop. Field evidence along the study road network indicates that the failed road section is underlain by mica schist, porphyritic granite, and phyllite. The reasonably stable portions are underlain by granite while the unaffected part underlays by medium grain granite/granite-gneiss, amphibolite schist, and sandstone.

\subsubsection{Mineralogy}

X-ray diffraction patterns of the basement rocks samples indicate predominance presence of quartz, biotite, muscovite, feldspar, and actinolite. While quartz, kaolinite, muscovite and anatase; for sandstone/mudstone Percentage mineralogical composition of granitic rocks from XRD result shows average structure. As of $33.5 \%$ quartz, $28.3 \%$ feldspar and $21.06 \%$ actinolite, muscovite schist shows average composition of $31.9 \%$ quartz, $30.3 \%$ feldspar and $22.4 \%$ muscovite while muscovite schist shows $33.1 \%$ quartz, $47.1 \%$ feldspar and $19.2 \%$ muscovite. Amphibolite schist shows $31.9 \%$ quartz, $27.1 \%$ feldspar and $21.06 \%$ actinolite. Phyllite shows average mineralogy composition of $44 \%$ quartz, $57 \%$ feldspar and $21 \%$ muscovite. Sandstone/mudstone shows the average composition of $75 \%$ quartz, $22.1 \%$ Kaolinite, $2.2 \%$ muscovite and anatase $2.5 \%$.

Percentage mineralogical composition of the rocks that underlain the disastrous section revealed a high proportion of feldspar minerals such as microcline, orthoclase, and albite. That was ranging between $30.3 \%$ and $57 \%$, and quartz varies between $32.1 \%$ and $34.9 \%$ (Table 1). The high feldspar content of these rocks coupled with the interaction of water will facilitate the chemical weathering of these rocks that may eventually yield clay minerals. 
Table 1: Percentage mineralogical composition of Basement Complex rock in the Study road

\begin{tabular}{|c|c|c|c|c|c|c|c|c|c|c|c|c|c|}
\hline Location & 1 & 2 & 3 & 4 & 5 & 6 & 7 & 8 & 9 & 10 & 11 & 12 & Total \\
\hline Granite $(\mathrm{KN})$ & 32 & 16 & n.d & n.d & 12.6 & n.d & n.d & 23.6 & n.d & 14.9 & n.d & n.d & 99.0 \\
\hline Muscovite schist (K/M) & 30.6 & n.d & 18.0 & 24.7 & n.d & n.d & n.d & 24.4 & n.d & n.d & n.d & n.d & 97.7 \\
\hline Muscovte schist (ZR) & 30.2 & n.d & 17.8 & 27.7 & n.d & n.d & n.d & 22.5 & n.d & n.d & n.d & n.d & 98.2 \\
\hline Muscovite schist (ABJ) & 31.8 & n.d & 24.5 & n.d & n.d & n.d & n.d & 41.0 & n.d & n.d & n.d & n.d & 97.7 \\
\hline Muscovite schist (KN) & 33.0 & n.d & 33.0 & n.d & n.d & n.d & n.d & 30.3 & n.d & n.d & n.d & n.d & 97.6 \\
\hline Ampbibolite (ZR) & 18.5 & 13.0 & n.d & n.d & 32.5 & n.d & n.d & 33.9 & n.d & n.d & n.d & n.d & 97.9 \\
\hline Phyllite (ZR) & 32.7 & 21.2 & n.d & n.d & $\mathrm{Nd}$ & 22.5 & n.d & 20.5 & n.d & n.d & n.d & n.d & 96.9 \\
\hline Granite $(\mathrm{KN})$ & 32.8 & n.d & n.d & n.d & 20.3 & n.d & n.d & 26.8 & 18.7 & n.d & n.d & n.d & 98.6 \\
\hline Granite gniess $(\mathrm{KN})$ & 46.2 & 21.6 & n.d & n.d & $\mathrm{Nd}$ & n.d & n.d & 21.7 & n.d & n.d & n.d & n.d & 99.5 \\
\hline Gniess mylonite (ZR) & 36.3 & n.d & n.d & n.d & 26.9 & n.d & 7.8 & 26.9 & n.d & n.d & n.d & n.d & 97.9 \\
\hline Sandstone (TA) & 72.3 & n.d & 2.2 & n.d & n.d & n.d & n.d & n.d & n.d & n.d & 21.4 & n.d & 98.9 \\
\hline Sandstone (KD) & 70.8 & n.d & 3.2 & n.d & n.d & n.d & n.d & n.d & n.d & n.d & 21.2 & 2.7 & 97.9 \\
\hline
\end{tabular}

Key: 1 = Quartz, 2 = Biotite, $3=$ Muscovite, 4 = Microcline, $5=$ Actinolite, $6=$ Othorclase, 7 = Chalcopyrite, $8=$ Albite, $9=$ Cordierite, $10=$ Iron magnesium aluminium silicate hydroxide, $\mathrm{n} . \mathrm{d}=$ not detected, $11=$ Kaolinite, $12=$ Anatase

\subsubsection{Geochemistry}

The geochemical analysis results of the rocks measured in weight percentage from the study road network as seen in the analyses which aided in the calculation and binary plots of the provenance and weathering intensity. The chemical composition of the rock samples is the direct reflection of the percentage composition of the rocks in the study area. Granite, Gneiss mylonite, and granite gneiss are characterized by $\mathrm{SiO}_{2}$ in the range of $62.93 \%$ and
$71.78 \%$, the schist, and phyllite in the range of $58.66 \%$ and $43.94 \%$, while amphibolite schist is $49.12 \%$. The relative enrichment of $\mathrm{Al}_{2} \mathrm{O}_{3}(17.08-17.20 \%), \mathrm{Na}_{2} \mathrm{O}$ and $\mathrm{K}_{2} \mathrm{O}$ in mica schist is an indication of it felsic character, feldspar and mica enrichment. The $\mathrm{Fe}_{2} \mathrm{O}_{3}$ and $\mathrm{MgO}$ enrichment in amphibolite schist and gneiss mylonite reflects mafic nature of these rocks. The sandstone enriched in $\mathrm{SiO}_{2}$ of $74.1 \%$ average composition, $20.1 \%$ kaolinite, $2.2 \%$ muscovite and $2.5 \%$ anatase.

Table 2: Major oxides in wt \% of Basement rocks in the study area

\begin{tabular}{|c|c|c|c|c|c|c|c|c|c|c|}
\hline Oxides & $\mathrm{K} / \mathrm{M}$ & $\mathrm{KN}$ & $\mathrm{KD}$ & ZR1 & ZR 2 & ZR 3 & TA1 & TA2 & KN1 & KD 1 \\
\hline $\mathrm{SiO}_{2}$ & 58.97 & 47.65 & 48.56 & 48.90 & 42.92 & 51.99 & 51.00 & 68.54 & 47.78 & 48.93 \\
\hline $\mathrm{Al}_{2} \mathrm{O}_{3}$ & 15.59 & 17.98 & 17.99 & 16.50 & 15.20 & 14.09 & 14.45 & 17.90 & 17.26 & 17.99 \\
\hline $\mathrm{Fe}_{2} \mathrm{O}_{3}$ & 4.91 & 7.91 & 7.88 & 10.50 & 10.14 & 3.62 & 3.32 & 4.00 & 2.91 & 5.32 \\
\hline $\mathrm{MgO}$ & 2.17 & 3.15 & 3.15 & 7.90 & 9.60 & 10.51 & 5.09 & 0.94 & 0.13 & 1.51 \\
\hline $\mathrm{Na}_{2} \mathrm{O}$ & 3.66 & 0.19 & 0.19 & 3.15 & 3.31 & 3.34 & 2.39 & 3.52 & 3.94 & 2.84 \\
\hline $\mathrm{K}_{2} \mathrm{O}$ & 2.53 & 4.76 & 4.76 & 5.21 & 3.16 & 2.14 & 6.44 & 4.76 & 5.43 & 2.14 \\
\hline $\mathrm{TiO}_{2}$ & 0.51 & 1.85 & 1.55 & 1.70 & 1.18 & 0.68 & 1.58 & 0.49 & 0.07 & 1.98 \\
\hline $\mathrm{P}_{2} \mathrm{O}_{5}$ & 0.14 & 0.04 & 0.04 & 0.04 & 0.14 & 0.12 & 0.03 & 0.14 & 0.02 & 0.05 \\
\hline $\mathrm{Cr}_{2} \mathrm{O}_{3}$ & 0.065 & 0.036 & 0.036 & 0.130 & 0.003 & 0.064 & 0.050 & 0.052 & 0.068 & 0.064 \\
\hline LOI & 0.66 & 5.90 & 5.99 & 5.09 & 6.09 & 1.38 & 6.44 & 0.48 & 0.50 & 6.38 \\
\hline Total & 91.26 & 91.06 & 90.77 & 100 & 100 & 91.37 & 100 & 99.42 & 82.40 & 87.28 \\
\hline
\end{tabular}

$\mathrm{K} / \mathrm{M}=$ Medium grained granite, KN.2 = Granite gneiss, Zar.1 = Phyllite, KN.1 = Muscovite schist, KN = Muscovite schist, TA1 = Mica schist, KN = Muscovite schist, TA2 = Gneiss mylonite, ZR $2=$ Muscovite schist, KD $=$ Sandstone

The geochemical binary plot of $\mathrm{Na}_{2} \mathrm{O} / \mathrm{Al}_{2} \mathrm{O}_{3}$ versus $\mathrm{K}_{2} \mathrm{O} / \mathrm{Al}_{2} \mathrm{O}_{3}$ shows that the mica schist, phyllite, and amphibolite schist are of sedimentary provenance, while granite and granite gneiss are of igneous origin [10].

Weathering intensity of igneous sandstones, and metamorphic rocks tropical climatic region can be determined using Ruxton Ratio $\left(\mathrm{SiO}_{2} / \mathrm{Al}_{2} \mathrm{O}_{3}\right)$. Ruxton proposed Ratio value of $<3.8$ for intensively weathered rocks, $4-4.5$ moderately weathered rocks and $>4.5$ least weathered rocks. The Ruxton Ratio values of between 2.6 - 3.7 showed the mica schist along Makarfi, Zaria, Kaduna, Niger areas phyllite and Abuja district amphibolite schist to have been intensively weathered and constituted the underlying basement rocks of the failed sections of the study road networks. While values of between $4.7-4.8$ revealed the granite/granite gneiss of some part of the Zaria as well, and the mylonite to be of least weathered intensity constituted the underlying basement rocks of the steady section of the study road networks. Combined field evidence, provenance study, and weathering intensity result show that the meta-sedimentary rocks are of low-grade metamorphism and have been intensively weathered while the metaigneous rocks are more steady and resistant to chemical weathering. The weathering forms move down discontinuities (planes of shortcoming), for example, faults and junctions, in the metasedimentary rock mass and then attack the faces, corners, and edges of the joints in rock, which produces flakes of clay and sand. As the cars and trucks weight pass over the weak spot (mud and sand) along the study road, pieces of the weathered material are weakened and cause the material to be displaced or broken down due to the vehicle overweight, creating potholes. Interaction of weathered materials (clay and sand) with water and frequent movement of cars and trucks causes the enlargement of potholes that resulted in total failure of the road section.

The steady portions of the study road that falls within the Zaria formation basin are composed of sandstone and ingenious rocky soil, which are formed in the deep-down ooze of sediments and rapid quartz grain as sandstone. Whereas the discharge of soluble ions leaves the more insoluble ions, principally Kaolinite, iron, and aluminum that precipitate of iron aluminum hydroxide as laterite.

Sandstone is more resilient for free water movement and chemical weathering associated to rocks contained more of silicates. Some clay influence swelling of weathered geological materials. Per se, clay minerals are usually regarded by it is characteristic minerals of the earths near surface hydrous environment. These consist of weathering, sedimentation, metamorphism, diagenesis or low grade and hydrothermal changes. Also, the presence of the thin layer of kaolinite non-swelling clay stone minerals in the sedimentary section of the study road does not have any swelling impact on the road. Similarly, diagenesis procedures such as compaction and cementation might influence hardening of the sandstone and thus make the road on the sedimentary section stable. However, this simply indicated that the unstable portion causes due to the weathering environment in such that the rocks and minerals they contain are changed by the processes determined in the biosphere and atmosphere respectively. 


\section{Conclusion}

In this study, combined mineralogy and geochemical evaluations of the monotonous (why monotonous) basement rocks and sandstone has been used to investigate the cause of road network failure along Kano-Abuja road, northern Nigeria. Results from this study identified the meta-sedimentary rocks which are of lowgrade metamorphism, enriched in feldspar minerals to underlie the failed sections of the study road network and meta-igneous rocks underlying the stable portions. The enrichment of feldspar combined with foliation, joints in the rocks and variation of climatic condition promote the weathering of the meta-sedimentary rocks that lead to intensive weathering of these rocks and cause the failure of some portions of the study road network and road carnage of various degree. The effort by the government agency to maintain the study road section has not yielded any fruitful result because the maintenance carried out was approached wrongly. It is evidently clear from this finding that low-grade metasedimentary rocks constitute the foundation of the failed section, the presence of clayey and sandy (weathered product) and interaction with climate have contributed to road failure witnessed on the study road section.

In the light of this study, the failed portions of the study road need serious engineering attention. Excavation to the new basement is required and filling with competent rocks to serve as basement and prevent persistent failure of this road.

\section{Acknowledgement}

The author would like to thank UniSZA for providing financial support for part of this research cost on the SRGS: (UniSZA/2017/SRGS/17) - R0019-R017, East Coast Environmental Research Institute (ESERI), UNISZA, Department of Physics, Yusuf Maitama Sule University, Kano, Kofar Nasarawa, Kano- Nigeria and Department of Geology, Kano University of Science and Technology, Wudil, Kano-Nigeria for give permission to use research facilities and supporting in this research.

\section{References}

[1] Kamarudin, M. K. A., Toriman, M. E., Wahab, N. A., Rosli, H. Ata, F. M., \& Faudzi, M. N. M. (2017). Sedimentation study on upstream reach of selected rivers in Pahang River Basin, Malaysia International Journal on Advanced Science, Engineering and Information Technology, 7(1), 35-41.

[2] Wahab, N. A., Kamarudin, M. K. A., Gasim, M. B., Umar, R., Ata F. M., \& Sulaiman, N. H. (2016). Assessment of total suspended sediment and bed sediment grains in upstream areas of Lata Berangin, Terengganu. International Journal on Advanced Science, Engineering and Information Technology, 6(5), 757-763.

[3] Sulaiman, W. N. A., Rosli, M. H., Abu Samah, M. A., \& Kamarudin, M. K. A. (2017). Landslide susceptibility mapping: Effect of spatial resolution towards the prediction of landslide prone area in a tropical catchment. Chiang Mai Journal of Science, 44(2), 494-507.

[4] Mohamed, A. D., Abd. Rahim, S., Aitman, D. A., \& Kamarudin, M. K. A. (2016). Analysis of seasonal soil organic carbon content at Bukit Jeriau Forest, Fraser Hill, Pahang. Malaysian Journal of Analytical Sciences, 20(2), 452-460.

[5] Abdullahi, M. G., Kamarudin, M. K. A., Umar, R., Gasim, M. B., \& Wahab, N. A. (2017). Assessment of natural groundwater recharge in Tudun Wada local government Kano State, Nigeria. Journal of Fundamental and Applied Sciences, 9(2S), 368-380.

[6] Kamarudin, M. K. A., Toriman, M. E., Rosli, M. H., Juahir, H., Aziz, N. A. A., Azid, A., Zainuddin, S. F., \& Sulaiman, W. N. A. (2015). Analysis of meander evolution studies on effect from land use and climate change at the upstream reach of the Pahang River, Malaysia. Mitigation and Adaptation Strategies for Global Change, 20(8), 1319-1334

[7] Osinowo O. O., Akanji A. O., \& Akinmosin A. (2011). Integrated geophysical and geotechnical investigation of the failed portion of a road in basement complex Terrain, Southwest Nigeria. RMZ Materials and Geoenvironment, 58(2), 143-162.
[8] Akintorinwa, O. J., Ojo J. S., \& Olorunfemi M. O. (2011) Appraisal of the causes of pavement failure along the Ilesa - Akure highway, Southwestern Nigeria using remotely sensed and geotechnical data Ife Journal of Science. 13(1), 185-197.

[9] Adewoye, A. O., Adegbola, A. A., Bolaji, A. A., \& Opebiyi, D. F. (2012). Engineering properties of foundational materials of Oyo, Ogbomoso road, in Southwestern Nigeria. Science Focus, 9, 42-47.

[10] Alabi, A. A. (2016). Geology, mineralogy, geochemical charaterization and provenance study of clay occurrences in central Bida/Niger basin, central Nigeria. PhD thesis, Ahmadu Bello Universit Zaria.

[11] Barry, O. C., Julie, R., Liz, R., Brian, D., Godfrey, B., Neil, M., Craig, H., Mike, H., Jamie, N., Craig, H., \& Louise, C. (2005). Geology, rocks and minerals developed for the geology. University of Auckland.

[12] Erdi-Krausz, G., Matolin, M., Minty, B., Nicolet, J.-P., Reford, W. S., \& Schetselaar, E. (2003). Guidelines for radioelement mapping using gamma ray spectrometry data. International Atomic Energy Agency Technical Documents (IAEA-TECDOCs) no. 2003; 1363.

[13] Hung, C. J., Monsees, J., Munfah, N., \& Wisniewski, J. (2009). Technical manual for design and construction of road tunnels-Civil elements. US Department of Transportation, Federal Highway Administration, National Highway Institute.

[14] Schlüter, T. (2008). Geological Atlas of Africa: with notes on stratigraphy, tectonics, economic geology, geohazards, geosites and geoscientific education of each country. Springer. 